\title{
Comparison of MODIS gross primary production estimates for forests across the U.S.A. with those generated by a simple process model, 3-PGS
}

\author{
J.M. Nightingale ${ }^{\text {a }}$, N.C. Coops ${ }^{b}$, R.H. Waring ${ }^{\text {a,* }}$, W.W. Hargrove ${ }^{\text {c }}$ \\ ${ }^{a}$ College of Forestry, Oregon State University, Corvallis, Oregon 97331, U.S.A. \\ b Department of Forest Resource Management, University of British Columbia Vancouver, Canada V6T 1Z4 \\ c Oak Ridge National Laboratory, Environmental Sciences Division, Oak Ridge, Tennessee 37831-6407, U.S.A.
}

Received 2 June 2006; received in revised form 23 January 2007; accepted 3 February 2007

\begin{abstract}
Since 2000, NASA's Moderate Resolution Imaging Spectro-radiometer (MODIS) has provided $1 \times 1 \mathrm{~km}$ estimates of 8 -day gross primary production (GPP). The MODIS algorithm computes GPP as a simple function of absorbed photosynthetically active radiation and a regionally assigned light-use conversion efficiency (LUE) that is reduced if temperature or atmospheric vapor pressure deficits are suboptimal. We compared MODIS-derived GPP estimates for forested areas across the United States of America (U.S.A.) with those generated by the 3-PGS (Physiological Principles Predicting Growth using Satellite data) model, the latter of which considers spatial variation in available soil water storage capacity (ASWC) and nitrogen content. We expected seasonal and annual MODIS GPP values to be in close agreement with those derived from the 3-PGS model in regions with adequate precipitation, soil water storage, and moderately fertile soils. 3-PGS was initially run with STATSGO-derived soils information provided by the Oak Ridge National Laboratory. The analysis was expanded to include sensitivity analyses with ASWC set at 50, 100, 300 , and $400 \mathrm{~mm}$ to identify areas within nine major ecoregions where drought might prove to be a major limitation on GPP. The majority of forests across the U.S.A. were relatively insensitive to large variations in ASW storage. In areas where ASWC was assumed $<200$ mm and average annual rainfall was $<100 \mathrm{~mm} \mathrm{yr}^{-1}$, GPP was predicted to be reduced by $>60 \%$. There was generally good agreement (within $20 \%$ ) between MODIS and 3-PGS estimates of forest GPP across the U.S.A. GPP predicted by the MODIS model was generally higher in ecoregions with substantial drought and with relatively low soil fertility. The latter, which influences LUE, was more than twice as important as soil drought. (C) 2007 Elsevier Inc. All rights reserved.
\end{abstract}

Keywords: MODIS GPP; 3-PGS; U.S.A. forests; Gross primary production; Available soil water capacity

\section{Introduction}

Evaluation of ecosystem level carbon dynamics is a key issue in global climate change research. Gross Primary Production (GPP), the photosynthetic uptake of carbon by plants, is an important variable in the global carbon cycle as roughly half of this is incorporated into new plant tissue, while the remainder is released back into the atmosphere through autotrophic respiration (Waring et al., 1998). Efforts to reduce uncertainty in the global carbon cycle require repeatable and consistent measures of the productivity of global terrestrial

\footnotetext{
* Corresponding author. Tel.: +1 541737 8481; fax: +1 5417371393.

E-mail addresses: Joanne.Nightingale@oregonstate.edu (J.M. Nightingale), nicholas.coops@ubc.ca (N.C. Coops), richard.waring@oregonstate.edu (R.H. Waring),hnw@fire.esd.ornl.gov (W.W. Hargrove).
}

ecosystems (Running et al., 2004; Wallin et al., 1997). Satellite remote sensing measurements of terrestrial productivity are a prerequisite to evaluate environmental degradation and the impacts of pollution and climate change (Running et al., 2004; Zhao et al., 2005). The MODIS (Moderate Resolution Imaging Spectro-radiometer) gross and net primary production products (MOD-17 A2 and MOD-17 A3, respectively), available since 2000, provide seasonal and inter-annual estimates of these two measures of vegetation productivity at $1 \times 1 \mathrm{~km}$ resolution.

Confirming the accuracy of MODIS products is challenging because of the difficulty in making direct measurements at the appropriate scale (Cohen et al., 2003; Gebremichael \& Barros, 2006; Turner et al., 2003b; Turner \& Urbanski, 2003a). Several studies have utilized data from a global ground-based monitoring network of micro-meteorological tower sites (FLUXNET (Baldocchi et al., 2001) and regional networks such as 
AmeriFLUX (Law et al., 2002)), where continuous measurement of eddy covariance fluxes provides estimate of GPP, as the sum of daytime net ecosystem production (NEP) and ecosystem respiration measured at night, adjusted for temperature differences during daylight hours (Heinsch et al., 2006; Turner et al., 2006, 2003b). Comparisons of MODIS 8-day, seasonal and annual GPP with data from these networks indicate that the MOD17 algorithm overestimates GPP on water-limited sites across the U.S.A. (Baldocchi et al., 2001; Heinsch et al., 2006; Turner et al., 2006, 2003b). Further research is required to determine whether this is a site-specific limitation or if it has implications at larger scales (Heinsch et al., 2006).

In addition to site-specific validation, there is a need to assess how well the MODIS GPP product captures variability at the regional level over a full range in climate and soil conditions (Morisette et al., 2002; Running et al., 1999; Turner et al., 2006). One approach to assess uncertainty in regional estimates of GPP is to use ecosystem process-based models that integrate a number of meteorological, biophysical and soil properties (De Pury \& Farquhar, 1997; Gebremichael \& Barros, 2006; Valentini et al., 1999). Ecosystem models provide reasonable estimates of the temporal and spatial variation in productivity given that sufficient soil and climate data are available.

Successful simulations depend on accurate approximations of soil water holding capacity because exhaustion of available water limits leaf conductance and the rates of photosynthesis and transpiration (Coops et al., 2001c; Running, 1994b; Running et al., 2004). It is very difficult, however, to obtain accurate regional information on soil water holding capacity, fertility and meteorology (Coops et al., 2001c; Landsberg \& Coops, 1999). Soils are inherently variable and soils maps are often inaccurate. The scale of most regional and continental soil maps ranges from 1:500000 to 1:1000 000, so there is tremendous variation within areas that are denoted as homogeneous (Landsberg \& Coops, 1999).

The lack of soil information at fine spatial scales, coupled with increasing evidence suggesting that MODIS GPP estimates are likely to be overestimated in areas with significant water limitations highlights the need to evaluate sensitivity of satellite-based broadscale predictions. Our general tenet is that seasonal and annual GPP estimated by the MOD-17 algorithm, should show a close association with estimates derived from a process-based forestgrowth model that contains both a monthly water balance and is sensitive to locally-defined soil fertility (Physiological Principles Predicting Growth using Satellite data, 3-PGS) only in regions with adequate precipitation, soil water storage and moderately fertile soils. Results of these analyses should enable us to distinguish cells and regions where variation in key soil properties is important and MODIS-derived estimates of productivity are likely to depart considerably from estimates made with 3-PGS.

\section{Data and methods}

\subsection{Overview of algorithms for estimating GPP}

\subsubsection{Estimation of GPP using the MOD-17 algorithm}

The MOD-17 GPP algorithm is described in detail by Running et al. (2004). In brief, the MODIS GPP product is based on the radiation conversion efficiency concept of Monteith (1972, 1977). MODIS-derived estimates of $f$ PAR (fraction of photosynthetically active radiation) and independent estimates of PAR are transformed using a light-use efficiency (LUE) value (ع) to derive gross primary production (Heinsch et al., 2003, 2006; Zhao et al., 2005). $\varepsilon$ is reduced from $\varepsilon_{\max }$ (the biomespecific maximum conversion efficiency) when minimum temperature and vapor pressure deficit (VPD) are less than optimal. There is no attempt to estimate transpiration and thus no requirement for precipitation data. The necessary meteorological information for global application at a resolution of $1.0^{\circ}$ by $1.25^{\circ}$ was acquired from satellite measurements and then interpolated to $1 \mathrm{~km}^{2}$, as will be described in more detail later.

Generalizations are made to assign a single $\varepsilon$ value to each of 12 broad land cover classes recognized in the MOD-12 University of Maryland (UMD) classification (http://geography.bu.edu/ landcover/userguide/index.html). The resulting Biome Properties Look Up Table (BPLUT) contains values specifying minimum temperature and VPD limits, specific leaf area (SLA) and respiration coefficients for the standard land cover classes (Heinsch et al., 2003). The requirement for near-real time calculation, and global application at a spatial resolution of $1 \mathrm{~km}$, results in the algorithm not being able to account explicitly for variation in soil properties. Instead, there is an implicit assumption that areas with infertile soils will support less canopy leaf area and therefore absorb less light than would be the case with vegetation growing on more fertile soils. Sources of error for the MOD-17 GPP algorithm relate to: (1) meteorology, (2) radiometry, and (3) biophysical variables required by the model. Algorithm verification efforts have led to a recalibration of all three of these factors in the most recently produced dataset (collection 4.5), utilized in this study (Heinsch et al., 2006; Zhao et al., 2005).

\subsubsection{Estimation of GPP using the 3-PGS model}

3-PGS was developed by Coops et al. (1998) as a simplified version of the original 3-PG model (Landsberg \& Waring, 1997). Upper limits on GPP are set by the amount of photosynthetically active radiation (PAR) absorbed by vegetation and the photosynthetic capacity (LUE) of the canopy. 3-PGS uses many of the principles that underlie earlier models such as FOREST-BGC (Running \& Coughlan, 1988), and BIOMASS (McMurtrie et al., 1990). Like these models, and the MOD-17 algorithm, 3-PGS first estimates absorbed photosynthetically active radiation (APAR) as a product of incident PAR (photosynthetically active radiation) and the fraction of PAR absorbed by the forest canopies (fPAR), which is estimated from the MOD-15A2 fPAR product. 3-PGS then calculates the utilized portion of APAR by reducing APAR by an amount determined by the most constraining of a series of environmental modifiers that affect gas exchange through stomata. These include: (a) high daytime atmospheric VPD; (b) soil water availability; and (c) the frequency of sub-freezing temperatures $\left(<-2{ }^{\circ} \mathrm{C}\right)$. In addition, photosynthesis can be further constrained by suboptimal temperatures, but this limitation was excluded from this analysis because sub-freezing temperature, low leaf area and low radiation limit photosynthesis during the winter and 
vegetation were assumed to experience near optimal temperatures during the growing season.

The Penman-Monteith equation is applied in 3-PGS to estimate transpiration from the canopy. This results in a monthly water balance that accounts for precipitation, drainage in relation to soil texture and withdrawal of water from the root zone to estimate the change in soil water availability (Coops et al., 2001a). The model predicts outflow when soil water content exceeds the estimated storage capacity. The soil water balance is calculated by taking into account the amount of water withdrawn from the soil through transpiration and the previous month's soil water supply through precipitation. In this study we ignore interception losses which may average $10-20 \%$ of available precipitation. 3-PG (and variants of this model) has been used to model the productivity of a wide range of forest types across regions of North America including: ponderosa pine (Law et al., 2000); lodgepole pine (Hall et al., 2006); loblolly pine (Landsberg et al., 2000); Douglas-fir (Coops et al., 2005); and jack pine (Peng et al., 2002). Model productivity estimates generally agree well with those measured. Even the hydrologic component, which is highly simplified, has been effective in capturing general trends in regional soil water depletion at monthly time steps (Coops \& Waring, 2001b, d; Coops et al., 2001a,c)

\subsection{Sources of data}

\subsubsection{MODIS and 3-PGS GPP}

MOD-17 collection 4.5 8-day GPP data were acquired from the Numerical Terradynamics Simulation Group (NTSG: http:// www.ntsg.umt.edu/) at the University of Montana and mosaicked to create surfaces for the contiguous U.S.A. from January 2000-December 2004. Monthly and annual GPP averages were derived by summing each 8-day period per month and per year (2000-2004). We applied the 3-PGS model at 1-km resolution for the contiguous U.S.A. for the five year period corresponding to the available MODIS GPP archive. Similar to the MODIS GPP dataset, monthly and annual averaged GPP were calculated for the 2000-2005 period. The following sections describe the datasets used within the 3-PGS model.

\subsubsection{Climate data}

We acquired daily meteorological observations (January 2000-December 2004) from the same NASA Data Assimilation Office (DAO) source utilized for the MODIS GPP algorithm (Schubert et al., 1993). Daily minimum and maximum temperature, daytime vapor pressure deficit and total shortwave radiation surfaces from this DAO dataset were provided by the NTSG. To interpolate the meteorological data, a non-linear interpolation routine was applied to rescale the coarse resolution $\left(1.0^{\circ} \times 1.25^{\circ}\right)$ DAO information down to $1 \times 1 \mathrm{~km}$ as described in Zhao et al. (2005). Daily values were averaged to provide the monthly climate surfaces required to run the 3-PGS model. Monthly estimates of precipitation were obtained from the PRISM (Parameter-Elevation Regressions on Independent Slopes Model) methodology available from the Oregon Climate Service (OCS) (Daly et al., 2004). Precipitation surfaces were originally produced at $4 \times 4 \mathrm{~km}$ resolution and were interpolated to $1 \times 1 \mathrm{~km}$ resolution for use within the 3 -PGS model.

\subsection{3. fPAR data}

Global monthly composites of MOD-15 fPAR data from 2000-2005 were acquired through the Climate and Vegetation Research Group at Boston University (http://cybele.bu.edu/ modismisr/index.html). Subsets of the continental U.S.A. were extracted and utilized in the 3-PGS model.

\subsubsection{Soil properties}

Soil maps delineated at scales of $1 \mathrm{~km}^{2}$ or coarser generally mask significant spatial variation in physical and chemical properties. Even with more precise mapping the fertility of forest soils would be difficult to judge as the same soil type may be commercially fertilized, may support nitrogen-fixing vegetation, or receive significant atmospheric depositions of nutrients (and pollutants). Most attempts to model plant growth have simply used mean values of soil properties applied across all forest conditions.

We were fortunate to have available two spatial layers of soil properties for the entire U.S.A., derived from cluster analysis of STATSGO soil parameters, terrain and climate observations from Oak Ridge National Laboratory (Hargrove \& Hoffman, 2004). The first layer provides spatial estimates of plant available soil water storage to $1.5 \mathrm{~m}$ depth and averaged $45 \mathrm{~mm}$ across the U.S.A. An average ASWC value of $200 \mathrm{~mm}$ is however, more realistic as has been demonstrated by relating to pre-dawn water potential measurements at drought-prone sites (Coops \& Waring, 2001b; Running, 1994a; Waring \& Cleary, 1967). We scaled the Oak Ridge plant-ASWC surface to provide soil water estimates to $5 \mathrm{~m}$ depth, which increased the average ASWC value to $\sim 150 \mathrm{~mm}$ across the U.S.A. Our approach was similar to that of Ollinger et al. (1998) who assumed for modeling purposes a constant value of $120 \mathrm{~mm}$ of ASWC across all soil types in New England. Scaling the ASWC data to $5 \mathrm{~m}$ was considered reasonable given that trees often rely on water stored in subsoil and at even greater depths in weathered bedrock (Hubbert et al., 2001; Jackson et al., 2000).

Soil fertility maps, estimated on the basis of Kjeldahl nitrogen analyses to $50 \mathrm{~cm}$ depth, were provided by Oak Ridge (Hargrove \& Hoffman, 2004). While soil nitrogen content is not a direct measure of available nitrogen, this is the only dataset with full coverage of the continental U.S.A. Spatial estimation of canopy LUE was derived from field-measured values at several experimental forest plots across the U.S.A., and ranged between 0.02-0.055 mol C/mol photon (Bond et al., 1999; Law et al., 2000; Waring et al., 1995). A logarithmic relationship was used to relate this to the range of soil nitrogen values across the continent (500-2000 $\mathrm{gN} \mathrm{m}^{-3}$ ) (Perakis et al., 2006; Swenson et al., 2005).

\subsubsection{Ecoregions and forest classes within the U.S.A.}

Forested areas across the U.S.A. were defined using the MODIS-derived University of Maryland (UMD) land cover classification scheme to facilitate comparison with the MOD-17 GPP product. This classification contains five forest classes: evergreen broadleaf, evergreen needleleaf, deciduous broadleaf, 
deciduous needleleaf; and mixed forest. To stratify the analysis further we defined forest located within broad ecological zones using the level I classification of North American ecological regions available from the United States Environmental Protection Agency (EPA) (http://www.epa.gov/wed/pages/ ecoregions.htm). The ecoregions are based on a classification derived from information on geology, landform, soils, vegetation, climate, wildlife and water resources (CEC, 1997). The level I classification comprises nine ecological regions within the continental U.S.A. Table 1 describes the UMD forest vegetation type present within these ecoregions and the percentage of forest cover.

\subsection{Modeling approach}

An analysis was conducted to determine which $1 \times 1 \mathrm{~km}$ forested cells across the contiguous U.S.A. were sensitive to

Table 1

EPA Level I ecoregions, percent forest defined using the MODIS land cover product UMD classification scheme as well as pie charts showing the relative sensitivity of forests to variations in ASWC within each ecoregion

\begin{tabular}{ll}
\hline Ecoregion & Percent Forest \\
\hline 5) Northern Forests & $78 \%$ \\
\hline
\end{tabular}

6) Northwestern Forested Mountains

$55 \%$

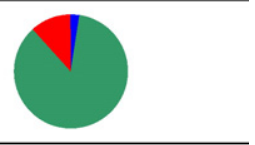

7) Marine West Coast Forest

$82 \%$

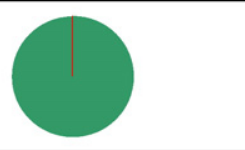

8) Eastern Temperate Forests

$33 \%$

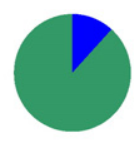

9) Great Plains

$1 \%$

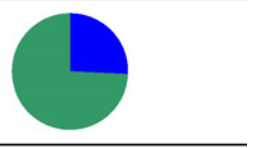

10) North American Deserts

$2 \%$

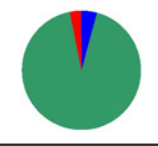

11) Mediterranean California

$7 \%$

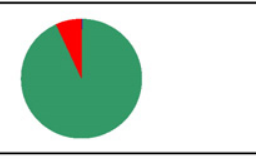

13) Temperate Sierras

$20 \%$

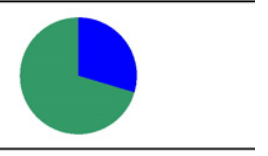

15) Tropical Wet Forests

$27 \%$

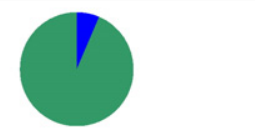

ASWC sensitivity key

Insensitive

$5-20 \%$ Sensitive

$>20 \%$ Sensitive a) Level I Ecoregions ASWC Reduced to $50 \mathrm{~mm}$

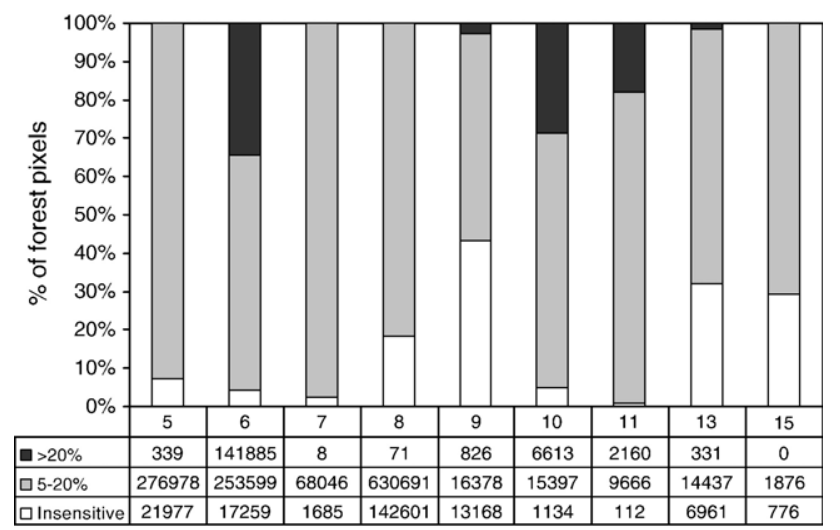

b) Level I Ecoregions ASWC Increased to $400 \mathrm{~mm}$

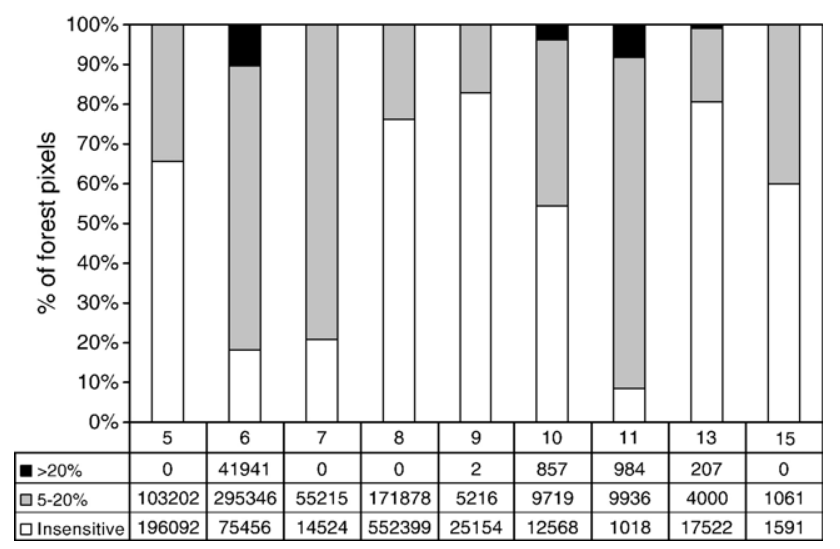

Fig. 1. a) Percentage change in 3-PGS derived GPP by ecoregions (5-15) when a) available soil water capacity (ASWC) is reduced to $50 \mathrm{~mm}$ from $200 \mathrm{~mm}$ and b) when ASWC is increased to $400 \mathrm{~mm}$ from $200 \mathrm{~mm}$.

changes in soil water content, based on variation observed in annual GPP predicted with 3-PGS. Initially, 3-PGS was run assuming a constant available soil water storage capacity value of $200 \mathrm{~mm}$ for all forested areas. The analysis was expanded by setting available soil water storage capacity at 50, 100,300 and $400 \mathrm{~mm}$. The effect of increasing or reducing ASWC on estimates of GPP was evaluated by univariate image differencing (Coppin et al., 2004) and by standardizing productivity estimates in reference to values simulated with ASWC set at $200 \mathrm{~mm}$. We separated the response to changing ASWC into three categories: (i) High, where changes in ASWC (reduction to $50 \mathrm{~mm}$ or increase to $400 \mathrm{~mm}$ ) resulted in a $>20 \%$ variation in GPP; (ii) Moderate, where changes in GPP ranged between $5-20 \%$; and (iii) Low, where GPP variations were $< \pm 5 \%$ indicating insensitivity to variations in ASWC. The proportion of cells classified to one of these three categories was then evaluated for each of the nine broad ecoregions. Once cells were classified according to their relative deviation from the standard run $(200 \mathrm{~mm})$, we compared both annual and seasonal MODIS GPP estimates to those predicted by the 3-PGS model using variable soil water storage and LUE scaled by soil nitrogen. 


\section{Results}

\subsection{Sensitivity of 3-PGS derived forest productivity to changing $A S W C$}

\subsubsection{Sensitivity of annual forest GPP}

On average, decreasing ASWC to $50 \mathrm{~mm}$ from $200 \mathrm{~mm}$ had only a moderate influence (5-20\% change) on annual forest GPP estimates within all level 1 ecoregions across the U.S.A. (Fig. 1a). Ecoregions containing forests that showed $>20 \%$ variation in GPP with a large reduction in ASWC were predominately in the south, central and western parts of the country and included: 6 (Northwestern forested mountains); 9 (Great Plains); 10 (North American Deserts); 11 (Mediterranean California); and 13 (Temperate Sierras) (Figs. 1a and 2). Ecoregions with a large proportion of forested pixels showing $<5 \%$ variation in GPP values from the standard ASWC of $200 \mathrm{~mm}$ included: 9 (Great Plains), 13 (Temperate Sierras) and 15 (Tropical Wet Forests) (Fig. 1a).

Increasing ASWC above $200 \mathrm{~mm}$ to a maximum of $400 \mathrm{~mm}$ resulted in only a modest increase in forest GPP averaging 5.5\% across the U.S.A. (Fig. 1b). A large proportion of forests in five ecoregions were relatively insensitive $( \pm 5 \%)$ to increases in ASWC: 5 (Northwestern forested mountains); 8 (Eastern temperate forests); 9 (Great plains); 10 (North American Deserts); 13 (Temperate sierras); and 15 (Tropical wet forests) (Figs. 1b and 2). There were, however, forests in ecoregions along the west coast that showed moderate to high sensitivity in predicted GPP with an increase in ASWC: 6 (Northwestern forested mountains); 7 (Marine West Coast Forest); 10 (North American Deserts); and 11 (Mediterranean California) (Figs. 1b and 2).

\subsubsection{Sensitivity at monthly time-steps}

We gained additional insight by analyzing monthly variation in GPP. For example, in ecoregion: 8 (Eastern temperate forests) there was relatively little seasonal sensitivity, whereas in ecoregion 7 (Marine West Coast Forest), moderate sensitivity to variations in ASWC appeared throughout the summer and early fall. The highest sensitivity and longest response to variations in ASWC was recorded in ecoregion 6 (Northwestern forested mountains) (Fig. 3). Forests in the east and west coast ecoregions were most sensitive to variation in available soil water storage capacity in the late spring, summer and early fall, with no substantial effect observed over the winter.

\subsection{Average annual GPP from 3-PGS and MOD-17}

3-PGS estimates of GPP range between $0.1-45.0 \mathrm{tC} \mathrm{ha}^{-1}$ $\mathrm{yr}^{-1}$, while MOD-17 estimates range between 0.4-34.0 $\mathrm{tC} \mathrm{ha}^{-1}$ $\mathrm{yr}^{-1}$ for forests across the U.S.A. Both models estimated average forest GPP at approximately $12 \mathrm{tC} \mathrm{ha}^{-1} \mathrm{yr}^{-1}$ across the country and the association between the two model estimates was high $\left(r^{2}=0.85, \mathrm{SE}=1.84 \mathrm{tC} \mathrm{ha}^{-1} \mathrm{yr}^{-1}, n=9\right)$ (Fig. 4).

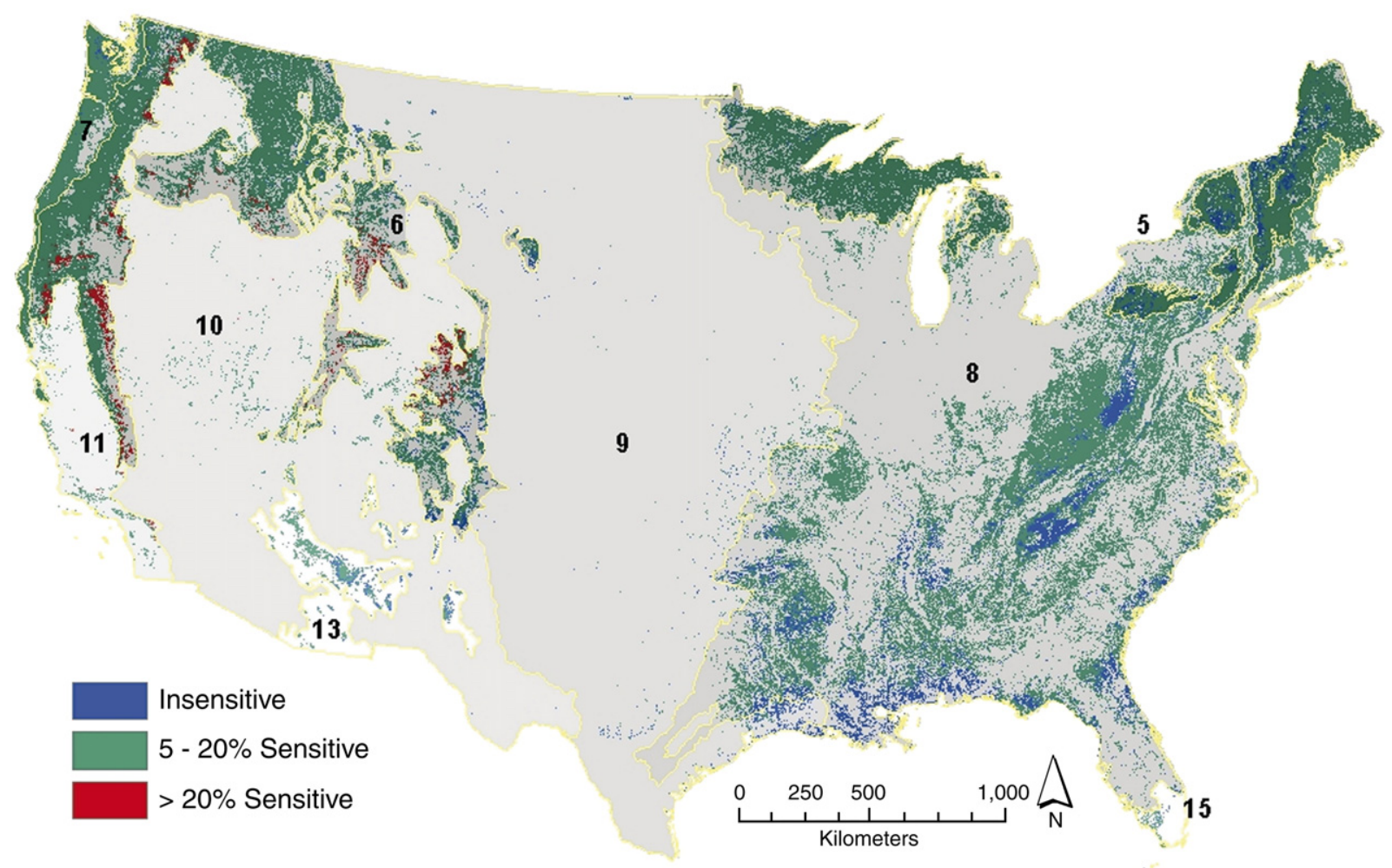

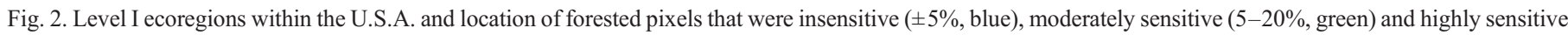

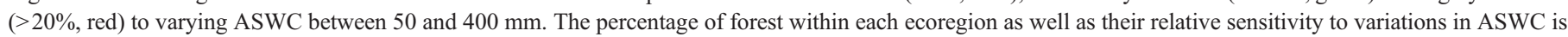
indicated by pie charts in Table 1 . 

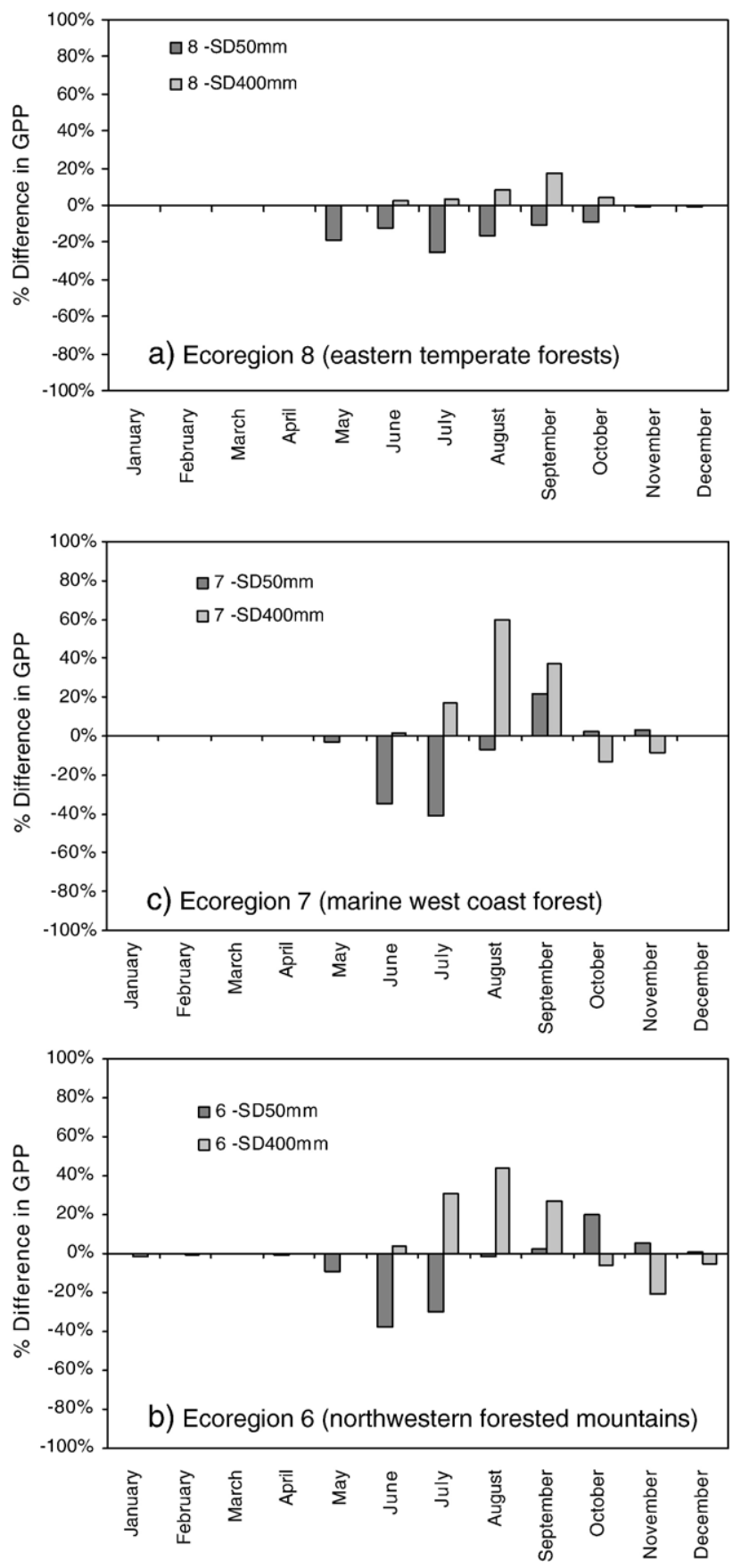

Fig. 3. Average response (percent Standardized Difference (SD)) to reducing ASWC to $50 \mathrm{~mm}$ and increasing to $400 \mathrm{~mm}$ on monthly 3-PGS estimates of GPP for ecoregions: a) 8 (eastern temperate forests); b) 7 (marine west coast forest); and c) 6 (northwestern forested mountains).

Average GPP estimates from both 3-PGS and MODIS tended to be lower $\left(<12.0 \mathrm{tC} \mathrm{ha}^{-1} \mathrm{yr}^{-1}\right)$ for forests located in the western half of the U.S.A. (ecoregions $6,9,10,11$ and 13) and higher $\left(>12.0 \mathrm{tC} \mathrm{ha}^{-1} \mathrm{yr}^{-1}\right)$ for forests along the eastern coast (ecoregions 5,8 and 15) with the exception of ecoregion 7 in the Pacific Northwest, which also has relatively high productivity (Fig. 4). MODIS generally predicted higher estimates of GPP than 3-PGS in regions with low-moderately fertile soils (ecoregions 6, 8, 10,11 and 13) than in ecoregions with higher

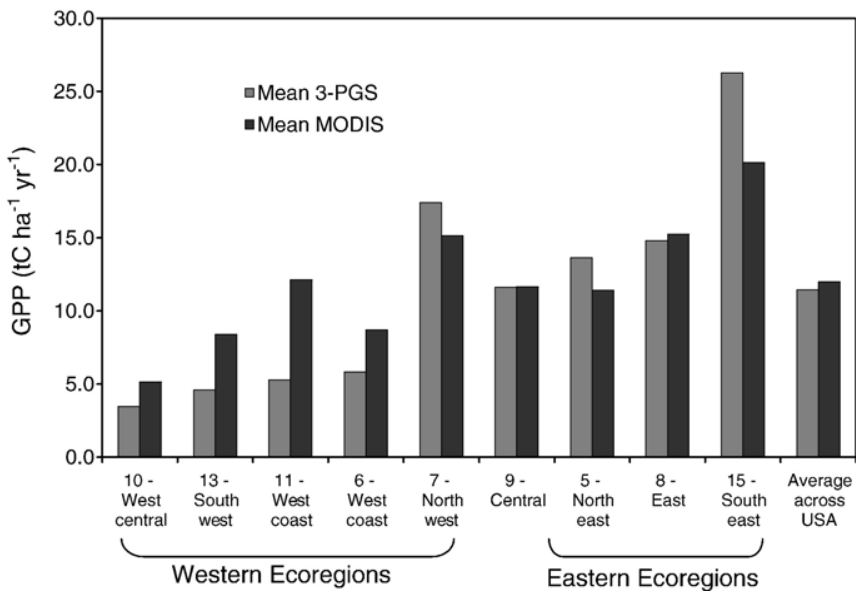

Fig. 4. Average annual estimates of GPP from the 3-PGS and MODIS models for level 1 ecoregions in the U.S.A. containing areas of forest. In comparison to 3PGS, MODIS tended to provide higher estimates of GPP to a greater extent in low-moderately productive ecoregions $(6,8,10,11$ and 13$)$ than in ecoregions with higher than average productivity $(7,15)$.

than average soil fertility $(5,7,15)$ (Fig. 4). However, estimates of GPP from 3-PGS and MODIS showed generally good agreement (within 20\%) across the country (Fig. 5). Considerable differences of up to $40 \%$ between model predictions of GPP were noted within ecoregions 11 (Mediterranean California) and 13 (Temperate Sierras) (Fig. 5).

As hypothesized, the association between MODIS and the 3-PGS GPP predictions improved by $20 \%$ when the comparison was restricted to forested cells insensitive to variation in ASWC (adjusted $R^{2}=0.89, \mathrm{SE}=1.47 \mathrm{tC} \mathrm{ha}^{-1} \mathrm{yr}^{-1}, n=9$ ) (Fig. 5). The percent standardized difference between MODIS and 3-PGS estimates was reduced in 3 eastern ecoregions (5, 8 and 15); however, differences between 3-PGS and MODIS GPP actually increased by up to $10 \%$ in other ecoregions (Fig. 5), perhaps reflecting a tradeoff between homogeneity and sample size.

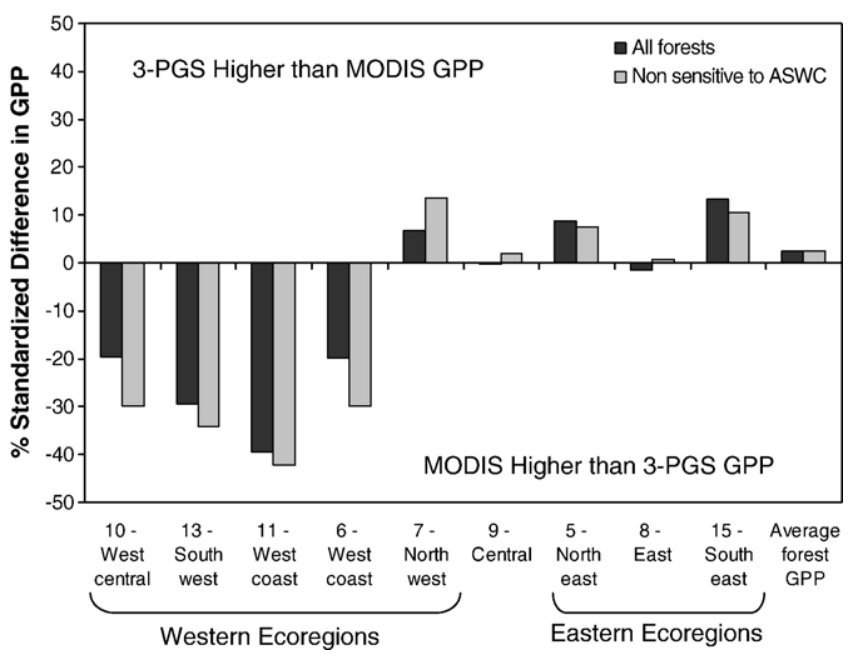

Fig. 5. Percent standardized difference in average annual forest GPP estimates predicted by 3-PGS and MODIS for all forest pixels located within EPA level I ecoregions and for forest pixels that were insensitive to variations in ASWC. 


\subsection{Average monthly GPP from 3-PGS and MODIS}

There was a high degree of association in relation to the magnitude and temporal dynamics of 3-PGS and MODIS average monthly estimates of forest GPP within each level I ecoregion. Fig. 6 shows the monthly traces of 3-PGS and MODIS predicted GPP for four selected ecoregions (5, 7, 9 and 10) that represent forests in the east, northwest, central and western U.S.A. (Fig. 2). The onset of photosynthetic activity in early spring and peak estimates of productivity in June, was not significantly different $(P<0.05)$ for both models within any of the nine broad ecological regions. However, the end of growing season was not clearly defined by either model. Only slightly better agreement between peak and end of growing season activity was attained with the two models by excluding forest cells sensitive to changes in ASWC.

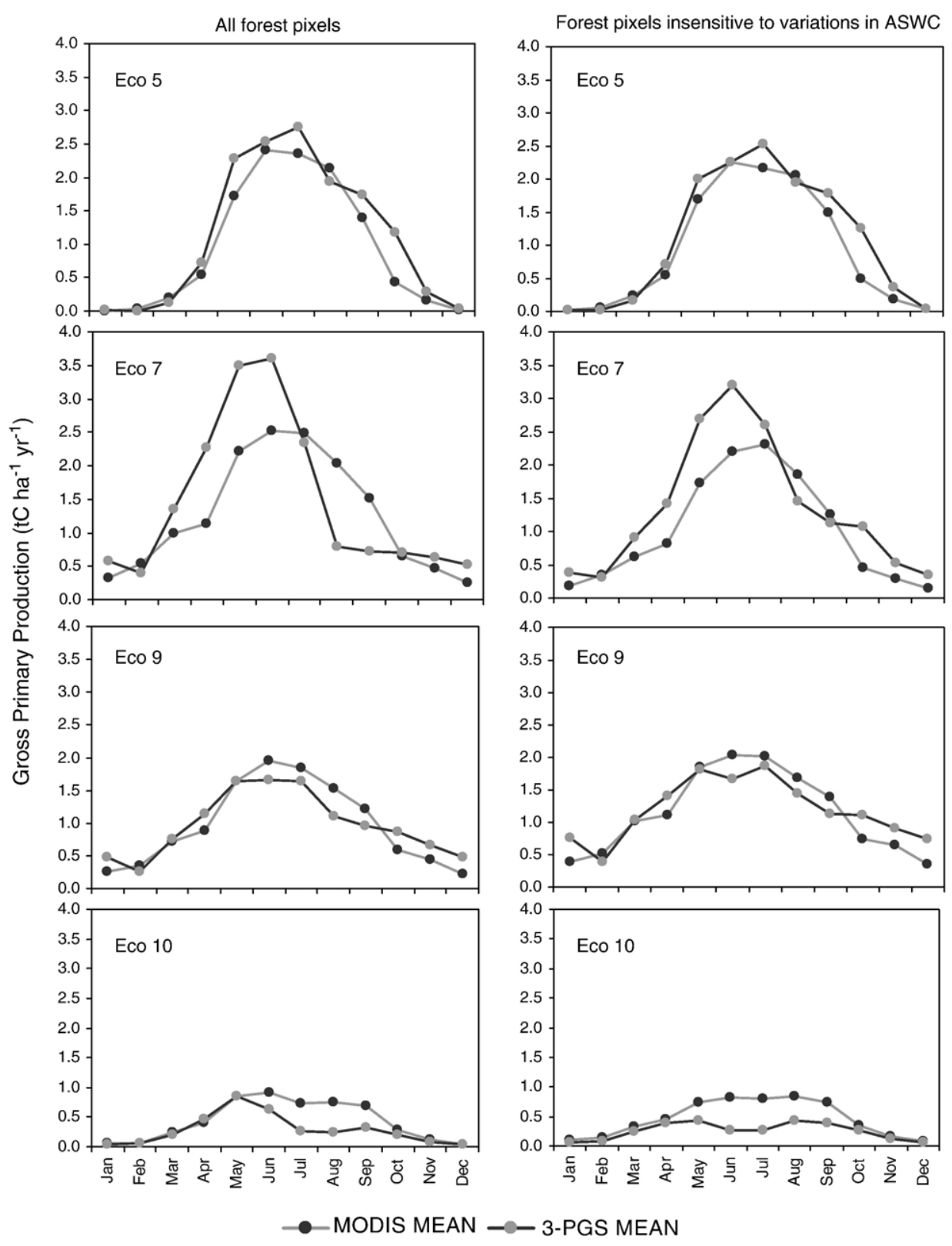

\section{Discussion}

\subsection{Sensitivity of GPP to changing $A S W C$}

In general, we found that the majority of forests across the U.S.A. are only marginally sensitive $(<20 \%$ change $)$ to alterations in ASWC. Forests in the western U.S.A. were more sensitive to changes in ASWC than those in the eastern part of the country. When available soil water capacity was reduced below $200 \mathrm{~mm}$ across the country, GPP fell on average by only $11 \%$. In specific areas, however, where ASWC was $<100 \mathrm{~mm}$ and annual precipitation of $<100 \mathrm{~mm}$ $\mathrm{yr}^{-1}$ such as that occurs in ecoregions 6, 9, 10, 11 and 13, GPP was predicted to drop by $>60 \%$. Conversely, increasing ASWC above $200 \mathrm{~mm}$ in areas where precipitation was

Fig. 6. Monthly traces of average GPP from 3-PGS and MODIS for all forest pixels (left) and for those insensitive to variations in ASWC (right) within selected ecoregions across the U.S.A. Ecoregions (Eco) are identified by number, with locations shown in Fig. 2. 
$>100 \mathrm{~mm} \mathrm{yr}^{-1}$ increased GPP by only $\sim 5 \%$ (e.g., in ecoregions 8 and 15).

The montane-Mediterranean climate of the western great plains and maritime-Mediterranean climate along the west coast are characterized by winter precipitation followed by an extended summer drought (Bauerle et al., 1999; Hubbert et al., 2001; Royce \& Barbour, 2001). Hence we see higher sensitivity to variation in ASWC in these regions than in the eastern U.S.A. (Fig. 2). Only sub-tropical forests located within ecoregion 15 showed moderate to high sensitivity to changes in ASWC during the winter months. The climate there enables year around photosynthetic activity, but is still limited by reduced precipitation, on drought-prone soils typical for in the interior parts of the ecoregion.

\subsection{Comparison of GPP derived from 3-PGS and MODIS}

There was generally good agreement (within 20\%) between MODIS and 3-PGS for all forests across the U.S.A. In alignment with results presented by several other studies, we noted that in comparison to 3-PGS, MODIS produced higher estimates of GPP to a greater extent in low to moderately productive ecoregions $(6,8,10,11$ and 13) than in ecoregions with higher than average productivity $(7,15)$ (Fig. 4) (Heinsch et al., 2006; Turner et al., 2006, 2003b; Zhao et al., 2005). Previous studies have attributed this to overestimates of $f$ PAR. In this study, however, we used the same $f$ PAR dataset for both models. We conclude that the higher average predictions of GPP made by the MODIS model are attributed to the higher LUE values being assigned to specific forest type than those derived with the 3-PGS model from correlations with soil fertility.

Considerable differences between GPP estimates from the two models are present for the forests located within the western and interior U.S. ecoregions $(6,10,11$ and 13). These western ecoregions contain relatively infertile soils with limited water storage capacity $(<100 \mathrm{~mm})$ and receive less than $100 \mathrm{~mm}$ of precipitation annually. As a result of the infertile soils, the LUE derived for use in the 3-PGS model is much lower than that assigned to the dominant vegetation class (evergreen needleleaf forest) used by the MOD-17 algorithm (Fig. 7). Across the 9 ecoregions, variation in predicted GPP was more closely related to the derived LUE than to ASWC $\left(R^{2}=0.69\right.$ vs. 0.31 , see Figs. 5 and 7$)$.

One of the strengths of the MODIS GPP model is its ability to capture seasonal dynamics in photosynthesis by establishing the beginning and end of the growing season (Heinsch et al., 2006; Zhao et al., 2005). We show that MODIS and 3 PGS exhibit close agreement at the beginning of the growing season in relation to the magnitude of predicted values. However, results of these analyses enable us to distinguish regions across the U.S.A. where variation in key soil properties are important and MODIS-derived estimates of GPP are likely to depart considerably from estimates made with 3-PGS, as shown in Fig. 6. Similar to results obtained for the annual average GPP, MODIS produces slightly higher estimates of growing season GPP than 3-PGS for forests in ecoregions with low-moderately fertile soils $(6,8,10,11$ and 13) and slightly

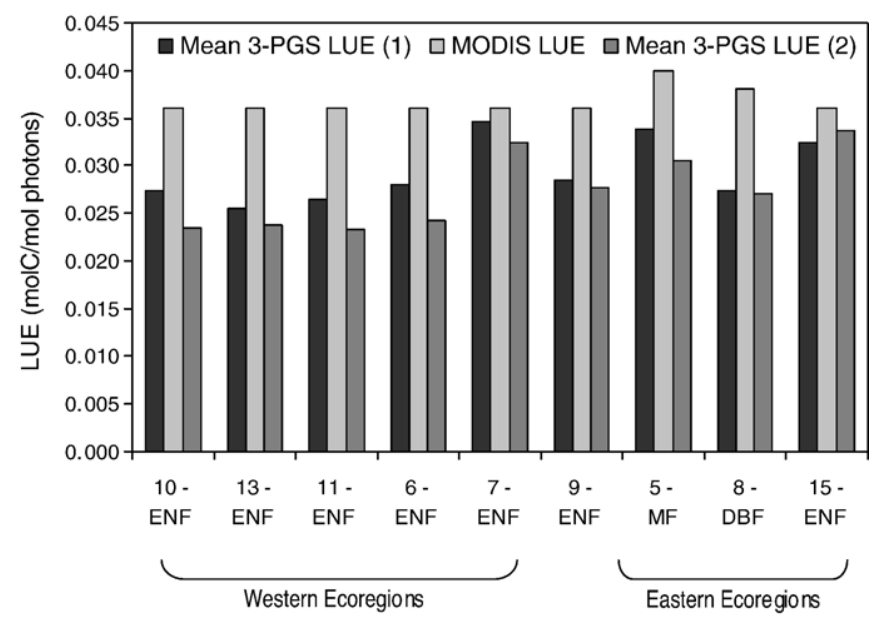

Fig. 7. Mean soil fertility-scaled LUE for all forests per level 1 ecoregion used within the 3-PGS model (LUE (1)), for forests insensitive to variations in ASWC (LUE (2)) and the corresponding LUE for the dominant vegetation class within each ecoregion for the MOD-17 GPP algorithm. Note: ENF (evergreen needleleaf forest); MF (mixed forest); and DBF (deciduous broadleaf forest).

less for forests in regions with relatively fertile soils (ecoregions 5, 7 and 15).

The reason MODIS tends to predict higher summer GPP within the majority of ecoregions across the U.S.A. compared to the 3-PGS model, is a result of having only two growth modifiers (relating to suboptimal temperatures and VPD). The 3-PGS model compensates for the underestimate of VPD in the DAO dataset by more rapidly depleting soil water supply than would be the case if more representative (higher) VPD values were introduced to reduce canopy stomatal conductance earlier in the growing season. Given that the MODIS algorithm does not account for soil moisture, GPP estimates might be expected to be consistently overestimated in drought-prone regions. We show, however, by excluding those forest pixels highly sensitive to variation in ASWC, that there was only a slight reduction in the difference between 3-PGS and MODIS GPP estimates during mid-summer and at the end of growing season. We conclude that the main reason for differences between model predictions pertains to the derivation of the LUE values (Fig. 7).

\section{Acknowledgements}

This work was funded by NASA grant \# NNG04GK26G. Meteorological data were provided by the NTSG group at the University of Montana. We are particularly grateful to Maosheng Zhao for providing interpolation code to allow us to utilize these datasets. In addition we thank scientists in GMAO, especially Mahendra K. Karki, for providing consistent GEOS-4 GMAO data and at UBC Thomas Hilker and Trevor Jones for efforts to interpolate and prepare the data for our specific needs. We acknowledge the PRISM group at the Oregon Climate Service for access to the gridded precipitation data for the US that was used in this analysis (PRISM Group, Oregon State University, http://www.prismclimate.org, created 4 Feb 2004). 


\section{References}

Baldocchi, D., Falge, E., Gu, L., Olson, R., Hollinger, D., Running, S., et al. (2001). FLUXNET: A new tool to study the temporal and spatial variability of ecosystem-scale carbon dioxide, water vapor and energy flux densities. Bulletin of the American Meteorological Society, 82, 2415-2435.

Bauerle, W. L., Hinckley, T. M., Cermak, J., \& Kucera, J. (1999). The canopy water relations of old-growth Douglas-fir trees. Trees, 13, 211-217.

Bond, B. J., Farnsworth, B. T., Coulombe, R. A., \& Winner, W. E. (1999). Foliage physiology and biochemistry in response to light gradients in conifers with varying shade tolerance. Oecologia, 120, 183-192.

CEC (1997). Ecological regions of North America: Toward a common perspective. Commission for Environmental Cooperation.

Cohen, W. B., Maiersperger, T. K., Yang, Z., Gower, S. T., Turner, D. P., Ritts, W. D., et al. (2003). Comparison of land cover and LAI estimates derived from ETM+ and MODIS for four sites in North America: A quality assessment of 2000/2001 provisional MODIS products. Remote Sensing of Environment, 88, 233-255.

Coops, N., Waring, R. H., \& Landsberg, J. J. (2001a). Estimation of potential forest productivity across the Oregon transect using satellite data and monthly weather records. International Journal of Remote Sensing, 22, 3797-3812

Coops, N. C., \& Waring, R. H. (2001b). Estimating forest productivity in the eastern Siskiyou Mountains of southwestern Oregon using a satellite driven process model, 3-PGS. Canadian Journal of Forest Research, 31, 143-154.

Coops, N. C., Waring, R. H., Brown, S. R., \& Running, S. W. (2001c). Comparisons of predictions of net primary production and seasonal patterns in water use derived with two forest growth models in Southwestern Oregon. Ecological Modelling, 142, 61-81.

Coops, N. C., \& Waring, R. H. (2001d). The use of multi-scale remote sensing imagery to derive regional estimates of forest growth capacity using 3-PGS. Remote Sensing of Environment, 75, 324-334.

Coops, N. C., Waring, R. H., \& Landsberg, J. J. (1998). Assessing forest productivity in Australia and New Zealand using a physiologically-based model driven with averaged monthly weather data and satellite-derived estimates of canopy photosynthetic capacity. Forest Ecology and Management, 104, 113-127.

Coops, N. C., Waring, R. H., \& Law, B. E. (2005). Predicting the influence of climate variability on the productivity and distribution of Ponderosa Pine Ecosystems in the Pacific Northwest. Ecological Modelling, 183, 107-124.

Coppin, P., Jonckheere, I., Nackaerts, K., \& Muys, B. (2004). Digital change detection methods in ecosystem monitoring: A review. International Journal of Remote Sensing, 25, 1565-1596.

Daly, C., Gibson, W. P., Doggett, M., Smith, J., \& Taylor, G. (2004). Up-to-date monthly climate maps for the conterminous United States. 14th AMS Conference on Applied Climatology Seattle, Washington: American Meteorological Society.

De Pury, D. G. G., \& Farquhar, G. D. (1997). Simple scaling of photosynthesis from leaves to canopies without the errors of big-leaf models. Plant, Cell and Environment, 20, 537-557.

Gebremichael, M., \& Barros, A. P. (2006). Evaluation of MODIS Gross Primary Productivity (GPP) in tropical monsoon regions. Remote Sensing of Environment, 100, 150-166.

Hall, R. J., Raulier, F., Price, D. T., Arsenault, E., Bernier, P. Y., Case, B. S., et al. (2006). Integrating remote sensing and climate data with process-based models to map forest productivity within west-central Alberta's boreal forest: Ecoleap-West. Forestry Chronicle, 82, 159-178.

Hargrove, W. W., \& Hoffman, F. M. (2004). The potential of multivariate quantitative methods for delineation and visualization of ecoregions. Environmental Management, 34, S39-S660.

Heinsch, F. A., Reeves, M., Votava, P., Kang, S., Milesi, C., Zhao, M., et al. (2003). Users Guide: GPP and NPP (MOD17A2/A3) Products NASA MODIS Land Algorithm (pp. 57). Missoula: University of Montana.

Heinsch, F. A., Zhao, M., Running, S., Kimball, J. S., Nemani, R. R., Davis, K. J., et al. (2006). Evaluation of remote sensing based terrestrial productivity from MODIS using regional Tower Eddy flux network observations. IEEE TGRS, 44, 1908-1925.
Hubbert, K. R., Beyers, J. L., \& Graham, R. C. (2001). Roles of weathered bedrock and soil in seasonal water relations of Pinus jeffreyi and Arctostaphylos patula. Canadian Journal of Forest Research, 31, 1947-1957.

Jackson, R., Sperry, J., \& Dawson, T. (2000). Root water uptake and transport: Using physiological processes in global predictions. Trends in Plant Science, 5, 482-488.

Landsberg, J. J., \& Coops, N. C. (1999). Modeling forest productivity across large areas and long periods. Natural Resource Modeling, 12, 383-411.

Landsberg, J. J., Johnsen, K. H., Albaugh, T. K., Allen, A. L., \& McKeand, S. E. (2000). Applying 3-PG, a simple process-based model designed to produce practical results, to data from Loblolly pine experiments. Forest Science, 47, $43-51$.

Landsberg, J. J., \& Waring, R. H. (1997). A generalized model of forest productivity using simplified concepts of radiation-use efficiency, carbon balance and partitioning. Forest Ecology and Management, 95, 209-228.

Law, B. E., Falge, E., Gu, L., Baldocchi, D., Bakwin, P., Berbigier, P., et al. (2002). Environmental controls over carbon dioxide and water vapor exchange of terrestrial vegetation. Agricultural and Forest Meteorology, $113,97-120$.

Law, B. E., Waring, R. H., Anthoni, P. M., \& Aber, J. D. (2000). Measurements of gross and net ecosystem productivity and water vapor exchange of a Pinus ponderosa ecosystem, and an evaluation of two generalized models. Global Change Biology, 6, 155-168.

McMurtrie, R. E., Rook, D. A., \& Kelliher, F. M. (1990). Modeling the yield of Pinus radiata on a site limited by water and nutrition. Forest Ecology and Management, 30, 381-413.

Morisette, J. T., Privette, J. L., \& Justice, J. O. (2002). A framework for the validation of MODIS land products. Remote Sensing of Environment, 83, 77-96.

Ollinger, S. V., Aber, J. D., \& Federer, A. (1998). Estimating regional forest productivity and water yield using an ecosystem model linked to a GIS. Landscape Ecology, 23, 323-334.

Peng, C. H., Liu, J. X., Dang, Q. L., Apps, M. J., \& Jiang, H. (2002). TRIPLEX: A generic hybrid model for predicting forest growth and carbon and nitrogen dynamics. Ecological Modelling, 153, 109-130.

Perakis, S. S., Maquire, D. A., Bullen, T. D., Cromack, K., Waring, R. H., \& Boyle, J. R. (2006). Coupled nitrogen and calcium cycles in forests of the Oregon Coast Range. Ecosystems, 9, 63-74.

Royce, E. B., \& Barbour, M. G. (2001). Mediterranean climate effects. I. Conifer water use across a Sierra Nevada Ecotone. American Journal of Botany, 88 , 911-918.

Running, S. (1994). Testing Forest-BGC ecosystem process simulations across a climate gradient in Oregon. Ecological Applications, 4, 238-247.

Running, S. W. (1994). Testing forest-BGC ecosystem process simulations across a climate gradient in Oregon. Ecological Applications, 4, 238-247.

Running, S., Nemani, R. R., Heinsch, F. A., Zhao, M., Reeves, M., \& Hashimoto, H. (2004). A continuous satellite-derived measure of Global terrestrial primary production. Bioscience, 54, 547-560.

Running, S. W., Baldocchi, D., Turner, D. P., Gower, S. T., Bakwin, P., \& Hibbard, K. A. (1999). A global terrestrial monitoring network integrating tower fluxes, flask sampling, ecosystem modeling and EOS satellite data. Remote Sensing of Environment, 70, 108-128.

Running, S. W., \& Coughlan, J. C. (1988). A general model of forest ecosystem processes for regional applications. I. Hydrologic balance, canopy gas exchange and primary production processes. Ecological Modelling, 42, 125-154.

Schubert, S., Rood, R., \& Others, A. (1993). An assimilated dataset for earth science applications. Bulletin of the American Meteorological Society, 74, 2331-2342.

Swenson, J., Waring, R. H., Fan, W., \& Coops, N. C. (2005). Predicting site index with a physiologically-based growth model across Oregon, USA. Canadian Journal of Forest Research, 35, 1697-1707.

Turner, D. P., Ritts, W. D., Cohen, W. B., Gower, S. T., Running, S. W., Zhao, M., et al. (2006). Evaluation of MODIS NPP and GPP products across multiple biomes. Remote Sensing of Environment, 102, 282-292.

Turner, D. P., Ritts, W. D., Cohen, W. B., Gower, S. T., Zhao, M., Running, S., et al. (2003a). Scaling Gross Primary Production (GPP) over boreal and deciduous forest landscapes in support of MODIS GPP product validation. Remote Sensing of Environment, 88, 256-270. 
Turner, D. P., \& Urbanski, S. (2003b). A cross-biome comparison of daily light-use efficiency for gross primary production. Global Change Biology, 9, 383-395.

Valentini, R., Baldocchi, D. D., \& Tenhunen, J. D. (1999). Ecological controls on land-surface atmospheric interactions. In J. D. Tenhunen \& P. Kabat (Eds.), Integrating Hydrology, Ecosystem Dynamics, and Biogeochemistry in Complex Landscapes (pp. 117-145). London: John Wiley \& Sons Ltd.

Wallin, D. O., Harmon, M. E., Cohen, W. B., Fiorella, M., \& Ferrell, W. K. (1997). Use of remote sensing to model land use effects on carbon flux in forests of the Pacific North West, USA. In H. L. Gholz, K. Nakane, \& H. Shimoda (Eds.), The Use of Remote Sensing in the Modeling of Forest Productivity (pp. 219-237). London: Kluwer Academic Publishers.

Waring, R. H., \& Cleary, B. D. (1967). Plant moisture stress: Evaluation by pressure bomb. Science, 155, 1248-1254.
Waring, R. H., Landsberg, J. J., \& Williams, M. (1998). Net primary production of forests: A constant fraction of gross primary production? Tree Physiology, 18.

Waring, R. H., Law, B. E., Goulden, M. L., Bassow, S. L., Mc Creight, R. W., Wofsy, S. C., et al. (1995). Scaling ecosystem production at Harvard Forest with remote sensing: A comparison of estimates from a constrained quantum-use efficiency model and eddy correlation. Plant, Cell and Environment, 18, 1201-1213.

Zhao, M., Heinsch, F. A., Nemani, R. R., \& Running, S. W. (2005). Improvements of the MODIS terrestrial gross and net primary production global data set. Remote Sensing of Environment, 95, 164-176. 